\title{
Table of select treaties and other international and regional instruments
}

Accord entre le gouvernement de la République du Sénégal et l'Union Africaine sur la création de chambres africaines extraordinaires au sein des juridictions Sénégalaises (22 August 2012) [EAC Accord]

African Charter on Human and Peoples' Rights (entered into force 21 October 1986), 1520 UNTS 217

African Charter on the Rights and Welfare of the Child (entered into force 29 November 1999), OAU Doc. CAB/LEG/24.9/49

Agreement between the United Nations and the Lebanese Republic on the Establishment of a Special Tribunal for Lebanon (6 February 2007), annex to UNSC Resolution 1757 (30 May 2007) [STL Statute]

Cape Town Principles and Best Practices on the Prevention of Recruitment of Children into the Armed Forces and Demobilization and Social Reintegration of Child Soldiers in Africa (27-30 April 1997) [Cape Town Principles]

Convention Against Torture and Other Cruel, Inhuman or Degrading Treatment or Punishment (entered into force 26 June 1987), 1465 UNTS 85 [CAT]

Convention Concerning the Prohibition and Immediate Action for the Elimination of the Worst Forms of Child Labour (ILO No. 182) (entered into force 19 November 2000), 2133 UNTS 161 [ILO Convention 182]

Convention on the Elimination of All Forms of Discrimination Against Women (entered into force 3 September 1981), 1249 UNTS 13 [CEDAW]

Convention on the Prevention and Punishment of the Crime of Genocide (entered into force 12 January 1951), 78 UNTS 277 [Genocide Convention]

Convention on the Rights of the Child (entered into force 2 September 1990), 1577 UNTS 3 [CRC]

Convention Relating to the Status of Refugees (entered into force 22 April 1954) 189 UNTS 137 [Refugee Convention]

European Convention for the Protection of Human Rights and Fundamental Freedoms, as subsequently amended (entered into force 3 September 1953), 213 UNTS 222 [ECHR]

Geneva Convention Relative to the Protection of Civilian Persons in Time of War (Fourth Geneva Convention) (entered into force 21 October 1950), 75 UNTS 287

International Covenant on Civil and Political Rights (entered into force 23 March 1976), 999 UNTS 171 [ICCPR]

International Covenant on Economic, Social and Cultural Rights (entered into force 3 January 1976), 993 UNTS 3 [ICESCR]

Law on the Establishment of the Extraordinary Chambers in the Courts of Cambodia for the Prosecution of Crimes Committed During the Period of Democratic Kampuchea, with inclusion of amendments (27 October 2004), NS/RKM/1004/006 [ECCC Law]

Optional Protocol to the Convention on the Rights of the Child on the Involvement of 
Children in Armed Conflict (entered into force 12 February 2002), 2173 UNTS 222 [OPAC]

Paris Commitments to Protect Children from Unlawful Recruitment or Use by Armed Forces or Armed Groups (February 2007) [Paris Commitments]

Paris Principles: Principles and Guidelines on Children Associated with Armed Forces or Armed Groups (February 2007) [Paris Principles]

Protocol Additional to the Geneva Conventions of 12 August 1949 and Relating to the Protection of Victims of International Armed Conflicts (entered into force 7 December 1978), 1125 UNTS 3 [Additional Protocol I]

Protocol Additional to the Geneva Conventions of 12 August 1949 and Relating to the Protection of Victims of Non-International Armed Conflicts (entered into force 7 December 1978), 1125 UNTS 609 [Additional Protocol II]

Rome Statute of the International Criminal Court (entered into force 1 July 2002), 2187 UNTS 90 [Rome Statute or ICC Statute]

Statute of the Special Court for Sierra Leone, annexed to the Agreement between the United Nations and the Government of Sierra Leone on the Establishment of the Special Court for Sierra Leone (entered into force 10 April 2002), 2178 UNTS 137 [SCSL Statute]

United Nations Standard Minimum Rules for the Administration of Juvenile Justice, adopted by General Assembly Resolution 40/33 of 29 November 1985 [Beijing Rules]

Universal Declaration of Human Rights, UNGA Resolution 217A(III) (10 December 1948) [Universal Declaration]

Vancouver Principles on Peacekeeping and the Prevention of the Recruitment and Use of Child Soldiers (15 November 2017) [Vancouver Principles] 
Mark A. Drumbl and Jastine C. Barrett - 9781788114486

Downloaded from PubFactory at 04/26/2023 09:35:35AM via free access 